\title{
The Role of Alcohol Consumption and Smoking Habits in Increasing the Diabetes Mellitus Risk in Adult Men and Women with Central Obesity in Indonesia: A Cross-Sectional National Study
}

\author{
Diyan Yunanto Setyaji ${ }^{1}$, Hiasinta Anatasia Purnawijayanti ${ }^{1}$. \\ ${ }^{1}$ Bachelor of Nutrition Program, Sekolah Tinggi Ilmu Kesehatan Panti Rapih, Yogyakarta, Indonesia \\ Correspondence: diyansetyaji@,stikespantirapih.ac.id
}

\begin{abstract}
Central obesity is more predictive of measuring the risk of type 2 diabetes compared to anthropometric indicators of general obesity. The results of previous studies are still inconsistent and the causal relationship that had not been well explained between the determinant factors and the increasing incidence of diabetes mellitus. This study aims to determine the relationship between alcohol consumption and smoking habits in increasing the risk of diabetes mellitus in adult males and females who are central obesity in Indonesia. The analysis presented in this study was based on the data from a population-based, cross-sectional, nationally representative survey (Indonesian Basic Health Research 2018/RISKESDAS 2018). In total, 12726 men and 18637 women aged 18-65 years were enrolled. A validated questionnaire, smoking card, and alcohol card were used for the assessments. There was a significant difference $(p<0.000)$ in the proportion of diabetes mellitus incidence between men and women in both age groups who consumed less than 1 pack of cigarettes or more than 1 pack per day. The age difference for the sexes did not show a statistically significant association with alcohol consumption of either under 5 servings or above 5 servings per day for the incidence of diabetes mellitus. Women with central obesity had an adjusted prevalence ratio of 1.7 times higher for diabetes mellitus than men. There were negative multiplicative interactions between sexes and smoking status (interaction $\mathrm{PR}=0.685 ; 95 \% \mathrm{CI}=0.52-0.88)$ and cigarette exposure $(0.65 ; 0.52-0.80)$ in women. The effects of alcohol consumption and their interactions with sex did not have a significant relationship. There is an increased risk of diabetes mellitus especially in women with central obesity. Alcohol consumption by people with central obesity has an interaction with gender in an increased risk of diabetes mellitus which is higher in women than men.
\end{abstract}

Keywords: Central obesity, diabetes mellitus, smoking, alcohol. 


\section{INTRODUCTION}

Diabetes mellitus is a chronic and progressive disease with an increasing prevalence and evidence during the last few decades around the world. The International Diabetes Federation (2017) states that the prevalence of diabetes mellitus in the world is $8.8 \%$ or about 425 million adults and is expected to increase to $9.9 \%$ in 2045 . The prevalence of diabetes mellitus in Indonesia is increasing very rapidly from $5.7 \%$ in in 2007 to $6.9 \%$ in 2013 and increased to $8.5 \%$ in $2018(1)$. These results place Indonesia as one of the countries with the highest diabetes mellitus in the world with an estimated number of 10.3 million in 2017 and is estimated to increase to 16.7 million in 2045(2). Diabetes mellitus was responsible for 4 million adult deaths in 2017 , which is the equivalent of one death every eight seconds. This disease also provides significant economic losses for the country, the health system, especially for people with diabetes and their families through direct medical costs and loss of jobs and wages $(2,3)$. In the past decade, it is estimated that health spending for adult diabetics has increased from $\$ 232$ billion to \$727 billion worldwide(2).

Being overweight is the most important modifiable risk factor for the development of type 2 diabetes because 85 $90 \%$ of people with type 2 diabetes are either overweight or obese. Waist circumference and waist-to-hip ratio as central anthropometric indicators of obesity are more predictive of the risk of developing type 2 diabetes compared to anthropometric indicators of obesity through body mass index measurement(4). A broad waist circumference indicates a high accumulation of abdominal fat. Central obesity as a clinical feature of excessive visceral fat accumulation is closely related to diabetes mellitus $(5,6)$. The prevalence of central obesity in Indonesia increased very rapidly from $18.8 \%$ in 2007 to $26.6 \%$ in 2013 and increased to $31 \%$ in $2018(1)$.

Diet has a major role in the development of central obesity. Alcoholic drinks contain quite high energy. The contribution of calories to alcohol in energy intake $(7.11 \mathrm{kcal} / \mathrm{g})$ falls between carbohydrates $(4 \mathrm{kcal} / \mathrm{g})$ and fat $(9 \mathrm{kcal} / \mathrm{g})$. Alcohol consumption $\geq 30$ g per day contributes to an increased risk of diabetes and central obesity, increased blood glucose concentration, and high blood pressure, especially in men(7). A crosssectional study showed that the total alcohol intake of men and women was directly related to high body mass index $\left(\geq 30.0 \mathrm{~kg} / \mathrm{m}^{2}\right)$ and broad waist circumference $(\geq 102 \mathrm{~cm}$ in men and $\geq 88$ $\mathrm{cm}$ in women)(8). Research by Park and Buja conducted on Korean and Italian 
societies shows that alcohol consumption will have a negative impact only on male groups $(9,10)$. A contrasting impact arises when alcoholic drinks are consumed in low to moderate amounts. Metaanalysis studies show that the prevalence of metabolic syndrome is two times lower in the group of women who consume moderate amounts of alcoholic beverages $(7,11,12)$.

Various community-based studies have shown that smoking is associated with high central obesity even though smokers have a low body weight or body mass index $(13,14,15,16,17,18)$. Although a lot of epidemiological evidence shows that there is a positive relationship between smoking habits and diabetes mellitus(19,20,21), various studies show insignificant results and even a negative relationship between the two $(22,23,24,25)$. Recent research from Wang shows that smoking is negatively associated with the incidence of type 2 diabetes in men of normal weight in China, but not significantly in the obese male or female group(26). A positive relationship from smoking actually appears related to the incidence of central obesity $(27,28)$ and stroke(26) in people with type 2 diabetes.

The results of the research are still inconsistent and the causal relationship that cannot be well explained between the determinant factors and the increasing incidence of diabetes mellitus in Indonesia can be caused by other smaller-scale studies that have not considered potential confounding factors such as race and genetic factors, gender, status, general obesity and central obesity, frequency and amount of alcohol intake, physical activity, disease history, and smoking habits. This study aims to determine the relationship between alcohol consumption and smoking habits in increasing the risk of diabetes mellitus in adult males and females who are central obesity in Indonesia. National scale data from Riskesdas 2018 is used to help provide results that can be applied in an effort to reduce the risk of diabetes mellitus in the entire population.

\section{METHODS}

We used a population-based, crosssectional, nationally representative survey (Indonesia Basic Health Research 2018/Riskesdas 2018/Riset Kesehatan Dasar 2018) conducted by the National Instituteof Health Research Development (NIHRD), Ministry of Health, Indonesia. A two-stage stratifified clustersampling method was used to draw the study sample from 34 provinces of the 514 Indonesian districts. Complete interviewswere conducted for 282.654 households from the targeted 300,000 households. The 1.091.528 participants were aged from 0 months to 75 years in the national survey, but ourstudy only focused on participants aged 18-65 years. In total, 12726 men and 
18637 women aged 18-65 years were enrolled.

First, we examined the characteristics of research participants according to gender and ageby using percentage. Second,chi-square tests were conducted to explore gender and age diferences in education, residency, and other variables. Third, the odds ratio (OR) and $95 \%$ confidence intervals (CIs) for the association of factors related to sociodemographic factors, smoking habits, and alcohol consumption with the incidence of diabetes mellitus in people with central obesity were estimated using logistic regressionanalysis. We controlled for all variables, such as residency, gender, age, education level, smoking and alcohol consumption in the regression analysis. In addition, we also stratified the models by smoking and alcohol consumption to investigate potential smoking and alcohol consumption diference in these associations. The IBM SPSS Statistics software (version. 23) was used for data analysis. The statistical threshold for significance was considered at $p \leq 0.05$.

\section{RESULTS}

Characteristics of research participants

All information in this study was obtained through Indonesia Basic Health Research 2018/Riskesdas 2018/Riset Kesehatan Dasar 2018. This data includes
31,363 people aged 18-65 years with central obesity for analysis of the role of alcohol consumption and smoking habits in the increased risk of diabetes mellitus in males and females with central obesity in Indonesia. There is no missing data after cleaning, so there is no drop out number in the data.

Table 1: Characteristics of research participantsaccording to gender and age

\begin{tabular}{|c|c|c|c|c|c|}
\hline \multirow{2}{*}{ Variables } & \multicolumn{4}{|c|}{ Men } & \multirow[t]{2}{*}{$p$ value } \\
\hline & Young & $\%$ & $\begin{array}{l}\text { Middle- } \\
\text { Aged }\end{array}$ & $\%$ & \\
\hline \multicolumn{6}{|l|}{ Education level } \\
\hline Graduate & 282 & 7,3 & 612 & 6,9 & \multirow[t]{2}{*}{, 358} \\
\hline Non-graduate & 3559 & 92,7 & 8273 & 93,1 & \\
\hline \multicolumn{6}{|l|}{ Occupation } \\
\hline Working & 3017 & 78,5 & 8326 & 93,7 & \multirow[t]{2}{*}{, $000 *$} \\
\hline Unemployed & 824 & 21,5 & 559 & 6,3 & \\
\hline \multicolumn{6}{|l|}{ Residency } \\
\hline Urban & 2003 & 52,1 & 4275 & 48,1 & \multirow[t]{2}{*}{, $000 *$} \\
\hline Rural & 1838 & 47,9 & 4610 & 51,9 & \\
\hline \multicolumn{6}{|l|}{ Smoking Status } \\
\hline Non-smoker & 935 & 24,3 & 1945 & 21,9 & \multirow{3}{*}{, $010^{*}$} \\
\hline $\begin{array}{l}\text { Smoking } \\
\text { occasionally }\end{array}$ & 576 & 15,0 & 1359 & 15,3 & \\
\hline Smoking ev eryday & 2330 & 60,7 & 5581 & 62,8 & \\
\hline \multicolumn{6}{|l|}{ Smoking habit } \\
\hline Never smoking & 935 & 24,3 & 1945 & 21,9 & \multirow[t]{2}{*}{, $002 *$} \\
\hline Smoking & 2906 & 75,7 & 6940 & 78,1 & \\
\hline \multicolumn{6}{|l|}{ Smoking exposure } \\
\hline Non-exposed & 255 & 6,6 & 830 & 9,3 & \multirow[t]{2}{*}{, $000^{*}$} \\
\hline Exposed & 3586 & 93,4 & 8055 & 90,7 & \\
\hline \multicolumn{6}{|l|}{$\begin{array}{l}\text { Number of } \\
\text { cigarettes }\end{array}$} \\
\hline Non-smoker & 943 & 24,6 & 1954 & 22,0 & \multirow{4}{*}{, $000^{*}$} \\
\hline 1-2 pack/day & 2531 & 65,9 & 5799 & 65,3 & \\
\hline 2-3 pack/day & 313 & 8,1 & 937 & 10,5 & \\
\hline$\geq 3 \mathrm{pack} /$ day & 54 & 1,4 & 195 & 2,2 & \\
\hline \multicolumn{6}{|l|}{$\begin{array}{l}\text { Alcohol } \\
\text { consumption }\end{array}$} \\
\hline $\begin{array}{l}\text { Non-alcoholic } \\
1-2 \text { portion/day }\end{array}$ & $\begin{array}{l}3499 \\
188\end{array}$ & $\begin{array}{l}91,1 \\
4,9\end{array}$ & $\begin{array}{l}8623 \\
146\end{array}$ & $\begin{array}{l}97,1 \\
1,6\end{array}$ & \multirow[t]{3}{*}{, $000^{*}$} \\
\hline $3-5$ portion/day & 83 & 2,2 & 66 & 0,7 & \\
\hline$>5$ portion/day & 71 & 1,8 & 50 & 0,6 & \\
\hline
\end{tabular}

$p$ values were from the Chi-squared test.

\begin{tabular}{|c|c|c|c|c|c|}
\hline \multirow{2}{*}{ Variables } & \multicolumn{4}{|c|}{ Women } & \multirow[t]{2}{*}{$p$ value } \\
\hline & Young & $\%$ & $\begin{array}{c}\text { Middle- } \\
\text { Aged }\end{array}$ & $\%$ & \\
\hline \multicolumn{6}{|l|}{ Education level } \\
\hline Graduate & 526 & 8,4 & 677 & 5,5 & \multirow[t]{2}{*}{, $000 *$} \\
\hline Non-graduate & 5768 & 91,6 & 11666 & 94,5 & \\
\hline \multicolumn{6}{|l|}{ Occupation } \\
\hline Working & 2450 & 38,9 & 6470 & 52,4 & \multirow[t]{2}{*}{, $000 *$} \\
\hline Unemployed & 3844 & 61,1 & 5873 & 47,6 & \\
\hline \multicolumn{5}{|l|}{ Residency } & \multirow{2}{*}{ 649 } \\
\hline Urban & 3249 & 51,6 & 6415 & 52,0 & \\
\hline
\end{tabular}




\begin{tabular}{|c|c|c|c|c|c|}
\hline Rural & 3045 & 48,4 & 5928 & 48,0 & \\
\hline \multicolumn{6}{|l|}{ Smoking Status } \\
\hline Non-smoker & 6122 & 97,3 & 11689 & 94,7 & \multirow{3}{*}{, $000 *$} \\
\hline $\begin{array}{l}\text { Smoking } \\
\text { occasionally }\end{array}$ & 118 & 1,9 & 351 & 2,8 & \\
\hline Smoking everyday & 54 & 0,9 & 303 & 2,5 & \\
\hline \multicolumn{6}{|l|}{ Smoking habit } \\
\hline Never smoking & 6122 & 97,3 & 11689 & 94,7 & \multirow[t]{2}{*}{, $000 *$} \\
\hline Smoking & 172 & 2,7 & 654 & 5,3 & \\
\hline \multicolumn{6}{|l|}{ Smoking exposure } \\
\hline Non-exposed & 1302 & 20,7 & 3232 & 26,2 & \multirow[t]{2}{*}{, $000 *$} \\
\hline Exposed & 4992 & 79,3 & 9111 & 73,8 & \\
\hline \multicolumn{6}{|l|}{$\begin{array}{l}\text { Number of } \\
\text { cigarettes }\end{array}$} \\
\hline Non-smoker & 6125 & 97,3 & 11691 & 94,7 & \multirow{4}{*}{, $000 *$} \\
\hline 1-2 pack/day & 162 & 2,6 & 622 & 5,0 & \\
\hline 2-3 pack/day & 6 & 0,1 & 23 & 0,2 & \\
\hline$\geq 3 \mathrm{pack} /$ day & 1 & 0,0 & 7 & 0,1 & \\
\hline \multicolumn{6}{|l|}{$\begin{array}{l}\text { Alcohol } \\
\text { consumption }\end{array}$} \\
\hline Non-alcoholic & 6264 & 99,5 & 12315 & 99,8 & \multirow{4}{*}{, $015^{*}$} \\
\hline 1-2 portion/day & 18 & 0,3 & 20 & 0,2 & \\
\hline $3-5$ portion/day & 2 & 0,0 & 3 & 0,0 & \\
\hline$>5$ portion/day & 10 & 0,2 & 5 & 0,0 & \\
\hline
\end{tabular}

$p$ values were from the Chi-squared test.

The characteristics of all study subjects are presented in Table 1. Adult males and females with central obesity were divided into two age category groups. The 18-35 year olds were categorized into young age and $36-65$ years into the middleage category. The proportion of women with central obesity who do not work is higher than that of men. In general, more centrally obese men are often exposed to secondhand smoke and have smoking and alcohol consumption in larger portions than women.

Relationship between the characteristics of research subjects and diabetes mellitus

Women with central obesity had a 1.7 times greater risk of developing diabetes mellitus than men for the same condition (95\% CI). Table 2 also shows that the increasing age of a person who has central obesity will be followed by an increased risk of suffering from diabetes mellitus. The 36-65 year age group had a 4 times greater risk of developing diabetes mellitus compared to younger people aged 18 to 35 years $(95 \% \mathrm{CI})$.

Table 2: Relationship between sociodemographic factors, smoking habits, and alcohol consumption with the incidence of diabetes mellitus in people with central obesity

\begin{tabular}{|c|c|c|c|c|c|c|}
\hline \multirow[b]{2}{*}{ Variables } & \multicolumn{4}{|l|}{ Diagnose } & \multirow[t]{2}{*}{$p$ value } & \multirow[t]{2}{*}{ OR } \\
\hline & $\begin{array}{l}\text { Non } \\
\text { Diabetes } \\
\text { melitus } \\
\end{array}$ & $\%$ & $\begin{array}{l}\text { Diabetes } \\
\text { melitus }\end{array}$ & $\%$ & & \\
\hline \multicolumn{7}{|l|}{ Sex } \\
\hline Men & 11771 & 92,5 & 955 & 7,5 & & \multirow{2}{*}{1,728} \\
\hline Women & 16345 & 87,7 & 2292 & 12,3 &, $000^{*}$ & \\
\hline \multicolumn{7}{|l|}{ Age } \\
\hline Young & 9762 & 96,3 & 373 & 3,7 & & \\
\hline Middle-aged & 18354 & 86,5 & 2874 & 13,5 &, $000^{*}$ & 4,098 \\
\hline \multicolumn{7}{|l|}{$\begin{array}{l}\text { Education } \\
\text { level }\end{array}$} \\
\hline Graduate & 1911 & 91,1 & 186 & 8,9 & & \\
\hline $\begin{array}{l}\text { Non- } \\
\text { graduate }\end{array}$ & 26205 & 89,5 & 3061 & 10,5 &, $021^{*}$ & 1,2 \\
\hline \multicolumn{7}{|l|}{$\begin{array}{l}\text { Occupation } \\
\text { level }\end{array}$} \\
\hline Working & 18298 & 90,3 & 1965 & 9,7 & & \\
\hline Unemployed & 9818 & 88,5 & 1282 & 11,5 &, $000 *$ & 1,216 \\
\hline \multicolumn{7}{|l|}{ Residency } \\
\hline Urban & 14283 & 89,6 & 1659 & 10,4 & & \\
\hline Rural & 13833 & 89,7 & 1588 & 10,3 &, 752 & 0,988 \\
\hline Smoking & 18200 & 88,0 & 2491 & 12,0 & & \\
\hline $\begin{array}{l}\text { Smoking } \\
\text { occasionally }\end{array}$ & 2175 & 90,5 & 229 & 9,5 &, $000 *$ & 0,769 \\
\hline $\begin{array}{l}\text { Smoking } \\
\text { everyday }\end{array}$ & 7741 & 93,6 & 527 & 6,4 &, $000 *$ & 0,497 \\
\hline \multicolumn{7}{|l|}{$\begin{array}{l}\text { Current } \\
\text { smoking } \\
\text { status }\end{array}$} \\
\hline $\begin{array}{l}\text { Smoking } \\
\text { occasionally }\end{array}$ & 1196 & 90,9 & 120 & 9,1 &, 056 & 0,790 \\
\hline $\begin{array}{l}\text { Smoking } \\
\text { everyday }\end{array}$ & 7255 & 94,2 & 186 & 11,3 &, $000^{*}$ & 0,489 \\
\hline \multicolumn{7}{|c|}{ Smoking habit } \\
\hline $\begin{array}{l}\text { Non-smoker } \\
\text { or ex-smoker }\end{array}$ & 19665 & 88,0 & 2677 & 12,0 & & \\
\hline $\begin{array}{l}\text { Active } \\
\text { smoking }\end{array}$ & 8451 & 93,7 & 570 & 6,3 &, $000 *$ & 0,495 \\
\hline \multicolumn{7}{|l|}{$\begin{array}{l}\text { Smoking } \\
\text { exposure }\end{array}$} \\
\hline $\begin{array}{l}\text { Non- } \\
\text { exposed }\end{array}$ & 4835 & 86,0 & 784 & 14,0 & & \\
\hline Exposed & 23281 & 90,4 & 2463 & 9,6 &, $000 *$ & 0,652 \\
\hline \multicolumn{7}{|l|}{$\begin{array}{l}\text { Number of } \\
\text { cigarettes }\end{array}$} \\
\hline$<1 \mathrm{pack} /$ day & 8481 & 93,1 & 633 & 6,9 &, $000 *$ & 0,546 \\
\hline >1 pack/day & 1414 & 92,1 & 122 & 7,9 &, $000 *$ & 0,631 \\
\hline \multicolumn{7}{|l|}{$\begin{array}{l}\text { Alcohol } \\
\text { consumption }\end{array}$} \\
\hline $\begin{array}{l}\text { Non- } \\
\text { alcoholic }\end{array}$ & 27489 & 89,5 & 3212 & 10,5 & & \\
\hline $\begin{array}{l}<5 \\
\text { portion/day }\end{array}$ & 472 & 94,4 & 28 & 5,6 &, $001 *$ & 0,508 \\
\hline $\begin{array}{l}>5 \\
\text { portion/day }\end{array}$ & 155 & 95,7 & 7 & 4,3 & ,014* & 0,387 \\
\hline
\end{tabular}

$p$ values were from the Chi-squared test. 
Central obesity adults who did not have tertiary education or who were unemployed had a 1.2 times higher risk of developing diabetes mellitus than those who had completed tertiary education or were employed $(95 \% \mathrm{CI})$. The area of residence did not show a statistically significant relationship with the incidence of diabetes mellitus in adults with central obesity ( $p$ 0.752). Smoking habits seen from various aspects such as smoking status, cigarette exposure, and the number of cigarettes consumed have a negative relationship with the incidence of diabetes mellitus in people with central obesity. People who never consumed alcohol had a tendency to develop diabetes mellitus 1.96 times and 2.58 times greater than those who consumed alcohol $<5$ servings ( $p$ 0.001) and $>5$ servings ( $p$ 0.014) per day.

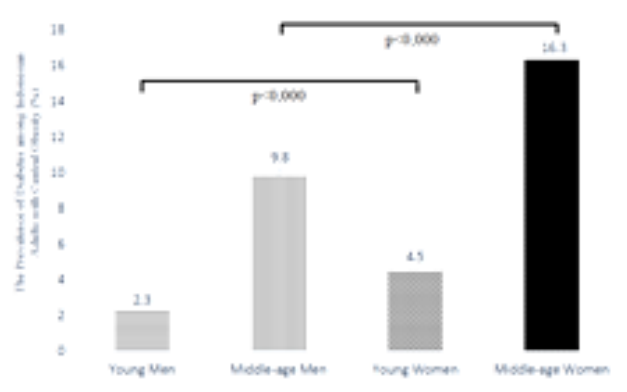

Figure 1: Prevalence of diabetes mellitus in indonesians with central obesity

Figure 1 shows a significant difference in the prevalence of diabetes mellitus in people with central obesity. In the young age group, the prevalence of diabetes mellitus was significantly higher in women than in men. Significant results were also found in the middle-age group. The prevalence of diabetes mellitus in people with central obesity increases with age. In women in the age range of 56-65 years, the prevalence of diabetes mellitus has decreased. The prevalence of diabetes mellitus was significantly higher in women compared to men in all age ranges (Figure 2).

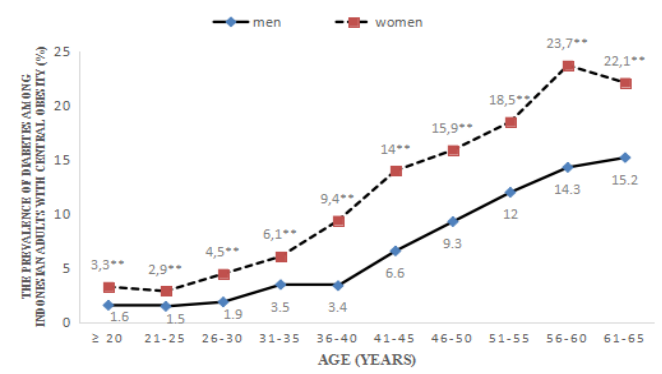

Figure 2: Prevalence of diabetes mellitus by age Footnote: **p Value $<0,000$

There was a significant difference $(p$ $<0.000$ ) in the proportion of diabetes mellitus incidence between men and women in both age groups who consumed less than 1 pack of cigarettes or more than 1 pack per day. Age differences for both sexes did not show a statistically significant association ( $p 0.094$ young age and $p 0.171$ middle-age) with alcohol consumption of either under 5 servings or above 5 servings per day for the incidence of diabetes mellitus (Figure 3). 


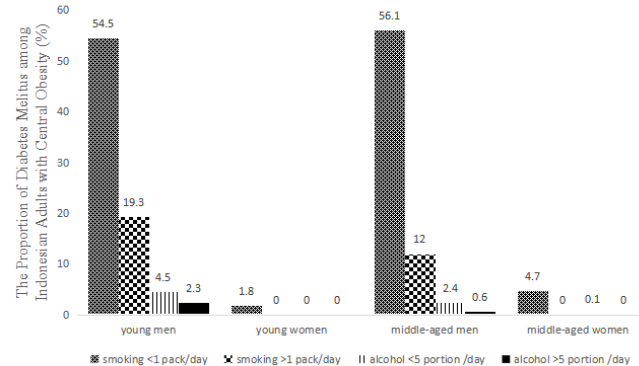

Figure 3: Prevalence of Diabetes Mellitus in Adults with Central Obesity by Age, Gender, and Consumption of Cigarettes and Alcohol

The stratification analysis of smoking status was carried out based on alcohol consumption, gender, age group, educational status, employment status, and living area to determine whether these variables influenced the relationship between smoking habits and the incidence of diabetes mellitus in people with central obesity. In smokers, almost all of the variables studied had a negative association with the risk of developing diabetes mellitus in people with central obesity. Compared to the group without tertiary education, the risk of developing diabetes mellitus was higher in smokers who had completed tertiary education, but this association was not statistically significant (Table 3).

Table 3: The stratification of smoking against diabetes mellitus according to alcohol consumption, gender, age group, educational status, work status, and area of residence

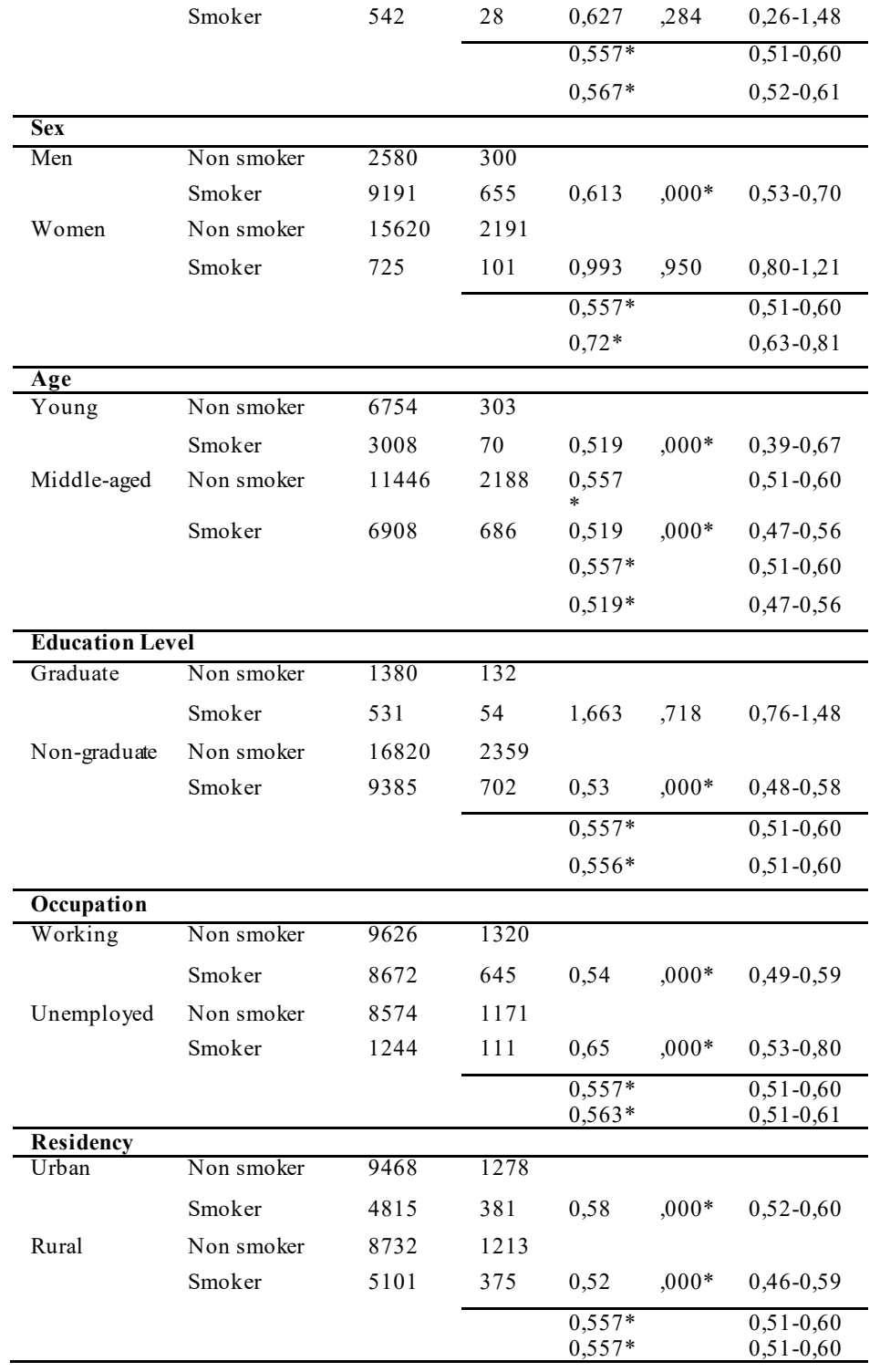

There is a quite large difference between the crude odd ratio value and the Mantel-Haenszel odd ratio on the gender variable. This suggests that gender is a confounder for the association of smoking status with the incidence of diabetes mellitus in people with central obesity.

\begin{tabular}{|c|c|c|c|c|c|c|}
\hline \multirow{2}{*}{ Strata } & \multirow{2}{*}{ Smoking status } & \multicolumn{2}{|c|}{$\begin{array}{l}\text { Diagnose of } \\
\text { Diabetes mellitus }\end{array}$} & \multirow[t]{2}{*}{ OR } & \multirow[t]{2}{*}{$p$} & \multirow[t]{2}{*}{$95 \%$ CI } \\
\hline & & No & Yes & & & \\
\hline \multicolumn{7}{|c|}{ Alcohol consumption } \\
\hline \multirow{2}{*}{$\begin{array}{l}\text { Non- } \\
\quad \text { alcoholic }\end{array}$} & Non smoker & 18115 & 2484 & & & \\
\hline & Smoker & 9374 & 728 & 0,56 &, $000 *$ & $0,52-0,61$ \\
\hline Alcoholic & Non smoker & 84 & 7 & & & \\
\hline
\end{tabular}


Table 4: Stratification of alcohol consumption on diabetes mellitus according to smoking status, gender, age group, educational status, work status, and a rea of residence

The quite large difference in the odds ratio in each class group in the gender and education variables indicates that these two variables are effect modifiers of the incidence of diabetes mellitus with smoking status in people who are centrally obese.

In centrally obese adults who consumed alcohol, all of the variables studied had a negative association with the risk of developing diabetes mellitus (Table 4). Smoking status, gender, and age group were confounders for the association of alcohol consumption with the incidence of diabetes mellitus in people with central obesity. Age group, education, and employment status are effect modifiers on the incidence of diabetes mellitus with alcohol consumption in people who are centrally obese.

\begin{tabular}{|c|c|c|c|c|c|c|}
\hline \multicolumn{7}{|c|}{ Education Level } \\
\hline Graduate & $\begin{array}{l}\text { Non- } \\
\text { Alcoholic }\end{array}$ & 1869 & 183 & & & \\
\hline & Alcoholic & 42 & 3 & 0,730 & ,599 & $0,22-2,37$ \\
\hline \multirow{3}{*}{$\begin{array}{l}\text { Non- } \\
\text { graduate }\end{array}$} & Non- & 25620 & 3029 & & & \\
\hline & Alcoholic & & & & & \\
\hline & Alcoholic & 585 & 32 & 0,463 &, $000 *$ & $0,32-0,66$ \\
\hline Crude OR & & & & 0,478 & & $0,33-0,67$ \\
\hline MH OR & & & & 0,478 & & $0,33-0,67$ \\
\hline \multicolumn{7}{|c|}{ Occupation } \\
\hline \multirow[t]{2}{*}{ Working } & $\begin{array}{l}\text { Non- } \\
\text { Alcoholic }\end{array}$ & 17775 & 1932 & & & \\
\hline & Alcoholic & 523 & 33 & 0,581 &, $002 *$ & $0,40-0,82$ \\
\hline \multirow[t]{2}{*}{$\begin{array}{l}\text { Unemploy } \\
\text { ed }\end{array}$} & $\begin{array}{l}\text { Non- } \\
\text { Alcoholic }\end{array}$ & 9714 & 1280 & & & \\
\hline & Alcoholic & 104 & 2 & 0,146 &, $002 *$ & $0,03-0,59$ \\
\hline $\begin{array}{l}\text { Crude OR } \\
\text { MH OR }\end{array}$ & & & & $\begin{array}{l}0,478 \\
0,496\end{array}$ & & $\begin{array}{l}0,33-0,67 \\
0,35-0,69\end{array}$ \\
\hline \multicolumn{7}{|l|}{ Residency } \\
\hline \multirow[t]{2}{*}{ Urban } & $\begin{array}{l}\text { Non- } \\
\text { Alcoholic }\end{array}$ & 13961 & 1640 & & & \\
\hline & Alcoholic & 322 & 19 & 0,502 &, $003 *$ & $0,31-0,80$ \\
\hline \multirow[t]{2}{*}{ Rural } & $\begin{array}{l}\text { Non- } \\
\text { Alcoholic }\end{array}$ & 13528 & 1572 & & & \\
\hline & Alcoholic & 305 & 16 & 0,451 &, $002 *$ & $0,27-0,74$ \\
\hline Crude OR & & & & 0,478 & & $0,33-0,67$ \\
\hline
\end{tabular}


condition. Smoking status, cigarette exposure, and alcohol consumption have a negative relationship with the incidence of diabetes mellitus. However, this only happened to men.

Table 5: Diabetes mellitus prevalence ratio according to gender

\begin{tabular}{|c|c|c|c|}
\hline Variables & PR & $95 \% \mathrm{CI}$ & $p$ Value \\
\hline \multicolumn{4}{|l|}{ Men } \\
\hline $\begin{array}{l}\text { Age (middle-aged } \\
\text { vs young) }\end{array}$ & 4,612 & $3,69-5,76$ &, $000 *$ \\
\hline Education & 0,677 & $0,54-0,84$ &, $001 *$ \\
\hline $\begin{array}{l}\text { Level(non- } \\
\text { graduate } \\
\text { graduate) }\end{array}$ & & & \\
\hline $\begin{array}{l}\text { Occupation } \\
\text { (unemployed vs } \\
\text { working) }\end{array}$ & 0,991 & $0,80-1,22$ & ,932 \\
\hline $\begin{array}{l}\text { Residency (rural } \\
\text { vs urban) }\end{array}$ & 0,885 & $0,77-1,01$ &, 070 \\
\hline $\begin{array}{l}\text { Smoking status } \\
\text { (smoker vs non- } \\
\text { smoker) }\end{array}$ & 0,613 & $0,53-0,70$ &, $000 *$ \\
\hline $\begin{array}{l}\text { Smoke exposure } \\
\text { (exposed vs non- } \\
\text { exposed) }\end{array}$ & 0,518 & $0,42-0,62$ &, $000 *$ \\
\hline $\begin{array}{l}\text { Alcohol } \\
\text { Consumption } \\
\text { (alcoholic vs non- } \\
\text { alcoholic) }\end{array}$ & 0,679 & $0,47-0,97$ &, $035^{*}$ \\
\hline \multicolumn{4}{|l|}{ Women } \\
\hline $\begin{array}{l}\text { Age (middle-aged } \\
\text { vs young) }\end{array}$ & 4,094 & $3,60-4,65$ &, $000 *$ \\
\hline Education & 1,723 & $1,38-2,13$ &, $000 *$ \\
\hline $\begin{array}{l}\text { Level(non- } \\
\text { graduate } \\
\text { graduate) }\end{array}$ & & & \\
\hline $\begin{array}{l}\text { Occupation } \\
\text { (unemployed vs } \\
\text { working) }\end{array}$ & 0,969 & $0,88-1,05$ & ,475 \\
\hline $\begin{array}{l}\text { Residency (rural } \\
\text { vs urban) }\end{array}$ & 1,056 & $0,96-1,15$ & ,228 \\
\hline $\begin{array}{l}\text { Smoking status } \\
\text { (smoker vs non- } \\
\text { smoker) }\end{array}$ & 0,993 & $0,80-1,22$ &, 950 \\
\hline $\begin{array}{l}\text { Smoke exposure } \\
\text { (exposed vs non- } \\
\text { exposed) }\end{array}$ & 0,795 & $0,72-0,87$ &, $000 *$ \\
\hline $\begin{array}{l}\text { Alcohol } \\
\text { Consumption } \\
\text { (alcoholic vs non- } \\
\text { alcoholic) }\end{array}$ & 0,388 & $0,12-1,24$ &, 098 \\
\hline
\end{tabular}

Multivariable analysis performed with logistic regression tests produced several regression models in analyzing the relationship between the incidence of diabetes mellitus in centrally obese adults and the factors that influence it. In the existing model, women with central obesity had an adjusted prevalence ratio of 1.7 times higher for diabetes mellitus than men. There were negative multiplicative interactions between sex and smoking status (interaction prevalence ratio $=0.685$; $95 \% \mathrm{CI}=0.52-0.88)$ and exposure to smoking $(0.65 ; 0.52-0.80)$ in women. The effects of alcohol consumption and their interactions with sex did not have a significant relationship.

Table 6: Diabetes mellitus prevalence ratio with respect to sociodemographic variables, smoking status, alcohol consumption, and their interactions

\begin{tabular}{|c|c|c|c|c|}
\hline Variables & PR & $95 \% \mathrm{CI}$ & $\begin{array}{l}p \\
\text { Value } \\
\end{array}$ & Psudo $R^{2}$ \\
\hline \multicolumn{5}{|l|}{ MODEL 1} \\
\hline $\operatorname{Sex}$ (women vs men) & 1,704 & $1,35-2,14$ &, $000 *$ & $7,3 \%$ \\
\hline $\begin{array}{l}\text { Age (middle-aged vs } \\
\text { young) }\end{array}$ & 4,331 & $3,87-4,84$ &, $000^{*}$ & \\
\hline $\begin{array}{l}\text { Education Level(non- } \\
\text { graduate vs graduate) }\end{array}$ & 1,117 & $0,95-1,30$ &, 173 & \\
\hline $\begin{array}{l}\text { Occupation } \\
\text { (unemployed } \\
\text { working) }\end{array}$ & 1,145 & $1,05-1,24$ &, $001 *$ & \\
\hline $\begin{array}{l}\text { Smoking status (smoker } \\
\text { vs non-smoker) }\end{array}$ &, 857 & $0,69-1,06$ &, 159 & \\
\hline Sex * Smoking Status & ,685 & $0,52-0,88$ &, $004 *$ & \\
\hline \multicolumn{5}{|l|}{ MODEL 2} \\
\hline Sex(women vs men) & 1,761 & $1,60-1,93$ &, $000 *$ & $7,3 \%$ \\
\hline $\begin{array}{l}\text { Age (middle-aged vs } \\
\text { young) }\end{array}$ & 4,245 & $3,79-4,74$ &, $000 *$ & \\
\hline $\begin{array}{l}\text { Education Level(non- } \\
\text { graduate vs graduate) }\end{array}$ & 1,123 & $0,95-1,31$ &, 153 & \\
\hline Occupation & 1,140 & $1,04-1,24$ &, $002 *$ & \\
\hline $\begin{array}{l}\text { (unemployed } \\
\text { working) }\end{array}$ & & & & \\
\hline Smoke exposure & 0,850 & $0,76-0,93$ &, $001 *$ & \\
\hline $\begin{array}{l}\text { (exposed vs non- } \\
\text { exposed) }\end{array}$ & & & & \\
\hline Sex * Smoke exposed & 0,650 & $0,52-0,80$ &, $000^{*}$ & \\
\hline \multicolumn{5}{|l|}{ MODEL 3} \\
\hline Sex(women vs men) & 0,886 & $0,25-3,02$ &, 847 & $7 \%$ \\
\hline $\begin{array}{l}\text { Age (middle-aged vs } \\
\text { young) }\end{array}$ & 4,295 & $3,84-4,80$ &, $000^{*}$ & \\
\hline $\begin{array}{l}\text { Education Level(non- } \\
\text { graduate vs graduate) }\end{array}$ & 1,072 & $0,91-1,25$ &, 387 & \\
\hline
\end{tabular}




\begin{tabular}{|c|c|c|c|c|}
\hline $\begin{array}{l}\text { Occupation } \\
\text { (unemployed } \\
\text { working) }\end{array}$ & 1,153 & $1,06-1,25$ &, $001 *$ & \\
\hline $\begin{array}{l}\text { Alcohol Consumption } \\
\text { (alcoholic vs non- } \\
\text { alcoholic) }\end{array}$ & 0,487 & $0,15-1,57$ & ,230 & \\
\hline $\begin{array}{ll}\text { Sex } \quad * & \text { Alcohol } \\
\text { Consumption } & \end{array}$ & 1,931 & $0,56-6,61$ & ,295 & \\
\hline \multicolumn{5}{|l|}{ MODEL 4} \\
\hline $\operatorname{Sex}(w o m e n$ vs men) & 1,711 & $1,36-2,14$ &, $000 *$ & $7,4 \%$ \\
\hline $\begin{array}{l}\text { Age (middle-aged } \\
\text { young) }\end{array}$ & 4,278 & $3,82-4,78$ &, $000 *$ & \\
\hline $\begin{array}{l}\text { Education Level(non- } \\
\text { graduate vs graduate) }\end{array}$ & 1,145 & $0,97-1,34$ & ,096 & \\
\hline $\begin{array}{l}\text { Occupation } \\
\text { (unemployed } \\
\text { working) }\end{array}$ & 1,137 & $1,04-1,23$ &, $003 *$ & \\
\hline $\begin{array}{l}\text { Smoking Status (smoker } \\
\text { vs non-smoker) }\end{array}$ & 0,885 & $0,71-1,09$ & ,269 & \\
\hline Smoke exposure & 0,54 & $0,77-0,94$ &, $002 *$ & \\
\hline $\begin{array}{l}\text { (exposed vs non- } \\
\text { exposed) }\end{array}$ & & & & \\
\hline Sex * Smoking Status & 0,733 & $0,56-0,96$ &, $024 *$ & \\
\hline Sex * Smoke exposed & 0,828 & $0,82-1,05$ &, 120 & \\
\hline
\end{tabular}

In the last model, sex, age, occupational status, cigarette exposure and smoking status interactions with sex have a significant and stable relationship. The ability of all independent variables in explaining the incidence of diabetes mellitus is shown by the pseudo R2 value in this model of $7.4 \%$. This means that there are still $92.6 \%$ of other factors outside the model that explain the incidence of diabetes mellitus in adults with central obesity. Although this model has the highest predictive value compared to other models, this model is not a simple model capable of explaining the incidence of diabetes mellitus in people with central obesity.

\section{DISCUSSION}

In this population-based study it was identified that there is a very close relationship between the risk of diabetes mellitus in centrally obese adults with an increase in age and gender, especially in women. Smoking habits and alcohol consumption have a negative relationship with the incidence of diabetes mellitus in centrally obese adults, but only significant in the male group. After adjusting for age, education level, occupation, the effect of female gender on central obesity was persistent and significant compared with men. There is also a positive interaction between the incidence of diabetes mellitus and alcohol consumption, especially in women, although it is not statistically significant.

The International Diabetes Federation (2017) states that the prevalence of diabetes mellitus in the world is $8.8 \%$ or about 425 million adults and is expected to increase to $9.9 \%$ in 2045 . The prevalence of diabetes mellitus in Indonesia is increasing very rapidly from $5.7 \%$ in in 2007 to $6.9 \%$ in 2013 and increased to $8.5 \%$ in $2018(1)$. The results of the 2018 Riskesdas showed that the prevalence of diabetes mellitus based on a doctor's diagnosis in adult women in Indonesia was $2.4 \%$, while in men it was $1.7 \%$. The same data shows an increase in the prevalence of diabetes based on examination of blood sugar levels using the 2015 Perkeni consensus, namely $12.7 \%$ in adult women and $9.0 \%$ in adult men. The highest prevalence of diabetes $(19.6 \%)$ is in the age group over 55 years(1). 
In the early adult age group, the prevalence of diabetes mellitus in people with central obesity was significantly higher in women $(4.5 \%)$ than in men $(2.3 \%)$. Significant results were also found in the late adult age group. The prevalence of diabetes mellitus in people with central obesity increases with age. In women in the age range of 56-65 years, the prevalence of diabetes mellitus has decreased. The prevalence of diabetes mellitus in people with central obesity is significantly higher in women than in men in all age ranges.

In this study, before adjusting with alcohol consumption, the risk of diabetes mellitus in women with central obesity was higher than that of men with central obesity related to smoking behavior. The negative relationship between smoking habits and the incidence of diabetes mellitus has also been shown by several previous studies $(22,23,24,25)$. Recent research from $\mathrm{Su}(26)$ shows that smoking is negatively associated with the incidence of type 2 diabetes in men in China, but not significantly in the female group. Smoking habits are associated with insulin resistance, inflammation, and dyslipidemia, but the exact mechanism regarding the effect of smoking on the incidence of diabetes mellitus is still not well explained(29). Inconsistent results between men and women were thought to be related to differences in smoking intensity, density, and duration. In Indonesia, Riskesdas data shows that only $1.2 \%$ of women over the age of 10 smoke every day, which is significantly lower than the proportion of men who smoke every day of $47.3 \%$ (1).

Alcohol consumption indicates a positive multiplicative effect on the risk of diabetes mellitus in women with central obesity, but it is not statistically significant. In the female group, alcohol consumption from $10.1 \mathrm{~g}$ to $15.0 \mathrm{~g}$ per day was associated with a higher risk of abnormal blood glucose concentrations(7). Alcohol contributes to $7,11 \mathrm{kcal} / \mathrm{g}$ of calories in energy intake. The proportion of women who consume alcohol in Indonesia is $0.4 \%$ (6.1\% men) and $0.0 \%(1.7 \%$ men $)$ for consuming alcohol in risky portions (above 5 servings per day or $50 \mathrm{~g}$ of pure ethanol per day).

Compared with the group who did not consume alcohol, a protective effect against diabetes mellitus appeared in the group who consumed alcoholic beverages. Previous meta-analysis studies showed that the prevalence of metabolic syndrome was two times lower in the group of women who consumed moderate amounts of alcoholic beverages $(7,11,12)$. Suliga(7) found that alcohol consumption is closely related to an increase in HDL cholesterol levels. The results in this study are different from the results of research by Park(9) and Buja(10) 
conducted on Korean and Italian societies which show that alcohol consumption will have a detrimental impact only on male groups. The differences in body composition and metabolism between the sexes and the type of alcohol consumed are thought to be the causes of differences in the risk of diabetes mellitus related to alcohol consumption.

The strength of this study is the use of data on a large scale and represent the adult population with central obesity in Indonesia. The questionnaire on cigarette and alcohol consumption was specific and used a visual image of alcoholic beverage packaging to equalize perceptions of the size used by research respondents. The standard unit size for alcoholic drinks is determined based on the type of alcoholic drink and the volume of its packaging. This makes the respondent's bias minimized. Second, this study is the first in Indonesia to explore the prevalence of diabetes mellitus in a population with central obesity and its relationship to smoking and alcohol consumption in the adult population.

However, the weakness of this study comes from the cross-sectional design used. Further studies with cohort designs are needed to investigate the differences in the effects of smoking and alcohol consumption in people with central obesity, especially in the female group. Furthermore, the researchers did not include other confounding variables such as co-morbidities, level of physical activity, consumption of risky foods.

\section{CONCLUSION}

Based on the 2018 Basic Health Research data, this study states that there is an increased risk of diabetes mellitus, especially in women with central obesity. The results also suggest that alcohol consumption by people with central obesity has an interaction with gender in an increased risk of diabetes mellitus in women compared to men.

Further longitudinal studies are needed to explore the different effects of smoking and alcohol consumption in people with central obesity. Communitybased health education programs need to be developed for various age groups, especially elderly people with central obesity, as well as increased physical activity even though they are not working and do not have adequate formal education.

\section{ACKNOWLEDGMENT}

The authors thank The National Institute of Health Research and Development (NIHRD), Ministry of Health Republic of Indonesia for providing us with the 2018 Riskesdas data. This work was supported by Sekolah Tinggi Ilmu Kesehatan Panti Rapih. The authors declare no conflict of interest. 


\section{REFERENCES}

1. National Institute of Health Research Development (NIHRD) Ministry of Health of Indonesia. Laporan Nasional Riskesdas 2018. Jakarta: Lembaga Penerbit Badan Penelitian dan Pengembangan Kesehatan. 2019.

2. IDF. Diabetes Atlas $8^{\text {th }}$ Edition. Brussels: The International Diabetes Federation [Internet]. 2017. Available from: https://www.idf.org/elibrary/epidemiology-research/diabetesatlas.html.

3. NCD Risk Factor Collaboration (NCDRisC). Worldwide trends in diabetes since 1980: a pooled analysisof 751 population-based studies with 4.4 million participants [Internet]. 2016. Available from: http://dx.doi.org/10.1016/S01406736(16)00618-8.

4. Bishal J, Laxmi S, Kushal B, Nilu M, Narayan BM. Comparison Of Central Obesity With Overall Obesity In Predicting The Risk Of Type 2 Diabetes Mellitus. Journal of Universal College of Medical Sciences, 7(1). 2019.

5. Lee M, Aronne LJ. Weight management for type 2 diabetes mellitus: global cardiovascular risk reduction. Am J Cardiol. 2007;99. p. 68-79.

6. Zhang C, Rexrode KM, van Dam RM. Abdominal obesity and the risk of all-cause, cardiovascular,and cancer mortality: sixteen years of follow-up in US women. Circulation. 2008;117(13). p. 16581667.

7. Suliga, et al. Consumption of Alcoholic Beverages and the Prevalence of Metabolic Syndrome and Its Components. Nutrients [Internet]. 2019;11,2764. Available from: https://doi:10.3390/nu11112764.

8. Tolstrup JS, Heitmann BL, Tjonneland AM. The relation between drinking pattern and body mass indexand waist and hip circumference. Int $\mathrm{J}$ Obes. 2005;29(5). p. 490-7.

9. Park S.H. Association between alcohol consumption and metabolic syndrome among Korean adults: Nondrinker versus lifetime abstainer as a reference group. Subst. Use Misuse. 2012;47. p. 442-449.

10. Buja A, Scafato E, Sergi G, et al. Alcohol consumption and metabolic syndrome in the elderly: Results from the Italian longitudinalstudy on aging. Eur. J. Clin. Nutr. 2010;64. p. 297-307.

11. Alkerwi A, Boutsen M, Vaillant M, et al. Alcohol consumption and the prevalence of metabolic syndrome: A meta-analysis of observational studies. Atherosclerosis. 2009;204. p. 624-635.

12. Traversy G, Chaput JP. Alcohol consumption and obesity: an update. CurrObes Rep. 2015;4(1). p. 12230.

13. Barnia C, Trichopoulou A, Lenas D, Trichopoulos D. Tobacco smoking in relationto body fat mass and distribution in a general population sample. Int. J. Obes. Relat. Metab. Disord. 2004;28.p. 1091-1096.

14. Barrett-Connor E, Khaw KT. Cigarette smoking and increased central adiposity. Ann. Intern. Med. 1989;111.p. 783-787.

15. Canoy D, Wareham N, Luben R, et al. Cigarette smoking and fat distribution in 21,828 British men and women: a population-based study. Obes. Res. 2005;13. p. 14661475.

16. Jee SH, Lee SY, Nam CM, Kim SY, Kim MT. Effect of smoking on the paradox of high waist-to-hip ratio and low body mass index. Obes. Res. 2002;10. p. 891-895.

17. Kim JH, Shim KW, Yoon YS. Cigarette smoking increases abdominal and visceral obesity but not overall fatness: an observational study. PLoS One. 2012;7. 
18. Shimokata H, Muller DC, Andres R. Studies in the distribution of body fat. III. Effects of cigarette smoking. JAMA. 1989;261. p. 1169-1173.

19. Akter S, Okazaki H, Kuwahara K, et al. Smoking, smokingcessation, and the risk of type 2 diabetes among Japanese adults: Japan Epidemiology Collaboration on Occupational Health Study. PLoS One. 2015;10(7).

20. Pan A, Wang Y, Talaei M. Relation ofactive, passive, and quitting smoking with incident type 2 diabetes: a systematic review and meta-analysis. The Lancet Diabetes \& Endocrinology. 2015;3(12). p. 958-967.

21. White WB, Cain LR, Benjamin EJ, et al. High-intensitycigarette smoking is associated with incident diabetes mellitus in black adults: the Jackson Heart Study. Journal of the American Heart Association. 2018;7(2).

22. Hou X, Qiu J, Chen P, et al. Cigarette smoking is associated with a lower prevalence of newly diagnosed diabetes screened by OGTT than non-smoking in Chinese men with normal weight. PLoS One. 2016;11(3).

23. Liu $Y$, Wang $K$, Maisonet $M$. Associations of lifestyle factors (smoking, alcohol consumption, diet and physical activity) with type 2 diabetes among American adults from National Health and Nutrition Examination Survey (NHANES) 2005-2014. Journal of Diabetes. 2017;9(9). p. 846-854.

24. Onat A, Ozhan H, Esen AM, et al. Prospective epidemiologic evidence of a "protective" effect of smoking on metabolic syndrome and diabetes among Turkish women-without associated overall health benefit. Atherosclerosis. 2007;193(2). p. 380-388.

25. Tsai AC, Lee SH. Determinants of new-onset diabetesin older adultsresults of a national cohort study. Clinical Nutrition. 2015;34(5). p. 937-942.

26. Su W. Cigarette Smoking is Negatively Associated with the Prevalence of Type 2 Diabetes in Middle-Aged Men with Normal Weight but Positively Associated with Stroke in Men. Journal of Diabetes Research [Internet]. 2019. Available from: https://doi.org/10.1155/2019/18530 18.

27. Akira F, Katsuyuki M, Sayaka K, et al. Lifetime cigarette smoking is associated with abdominal obesity in a community-based sample of Japanese men: The Shiga Epidemiological Study of Subclinical Atherosclerosis (SESSA). Preventive Medicine Report [Internet]. 2016;4. p. 225232. Available from: https://doi.org/10.1016/j.pmedr.201 6.06.013.

28. Eun J. Smoking Is Associated With Abdominal Obesity, Not Overall Obesity, In Men With Type 2 Diabetes. J Prev Med Public Health. 2012;45. p. 316-322.

29. Śliwińska-Mossoń M. The impact of smoking on the development of diabetes and its complications. Diabetes \& Vascular Disease Research. 2017;14(4). p. 265-276. 